\title{
Penerapan Model Discovery Learning Berkolaborasi Google Classroom dan WhatsApp Group untuk Meningkatkan Kompetensi Siswa dalam Menulis Teks Eksplanasi
}

\author{
Waginah Dwi Nuryaningsih \\ SMP Negeri 3 Bojong, Kabupaten Pekalongan - Provinsi Jawa Tengah \\ Corresponding Author. Email: dwiginah@gmail.com
}

\begin{abstract}
This study aims to describe the increase in activeness and learning outcomes of writing explanatory text in Indonesian subjects by implementing the Discovery Learning model through the online-based Whatsapp Group assisted by Google Classroom during the Covid-19 pandemic. The method used was classroom action research with a research design using the model of Kemmis and Mc Taggart which consisted of planning, implementing, observing, and reflecting stages. The subjects of this study were students of class VIII A SMP Negeri 3 Bojong, Pekalongan Regency. The technique of collecting data by means of interviews, observation, questionnaires and tests. While the data analysis technique used qualitative and quantitative descriptive analysis. The results of the research in the pre-cycle showed student activeness was $6.25 \%$, in the first cycle it increased to $28.13 \%$, and in the second cycle it increased by $15.62 \%$. From the test results in the pre-cycle the average value was 69 , in the first cycle it increased to 73, and in the second cycle it became 76. Students who achieved learning completeness in the pre-cycle $12, \%$, in the first cycle were 15.63 , and in the second cycle it became $84.38 \%$. It can be concluded that with the application of the Discovery Learning learning model through Google Classroom assisted by online-based Whatsapp Group during the Covid-19 pandemic, it can increase the activeness and learning outcomes of competency / explanatory text material for class VIII A students of SMP Negeri 3 Bojong.
\end{abstract}

\begin{abstract}
Abstrak: Penelitian ini bertujuan untuk mendiskripsikan peningkatan keaktifan dan hasil belajar menulis teks eksplanasi pada mata pelajaran Bahasa Indonesia dengan penerapan model pembelajaran Discovery Learning melalui Google Classroom berbantukan Whatsapp Group berbasis daring pada masa pandemi Covid-19. Metode yang digunakan adalah penelitian tindakan kelas dengan desain penelitian menggunakan model Kemmis dan Mc Taggart yang terdiri dari tahap perencanaan, pelaksanaan, observasi, dan refleksi. Subjek penelitian ini siswa kelas VIII A SMP Negeri 3 Bojong Kabupaten Pekalongan. Teknik pengumpulan data dengan wawancara, observasi, angket dan tes. Sedangkan teknik analisis datanya menggunakan analisis deskriptif kualitatif dan kuantitatif. Hasil penelitian pada pra siklus menunjukan keaktifan siswa $6,25 \%$, pada siklus I meningkat menjadi $28,13 \%$, dan pada siklus II meningkat lagi 15 , $62 \%$. Dari hasil tes pada pra siklus rata-rata nilai 69 , pada siklus I naik menjadi 73, dan pada siklus II menjadi 76. Siswa yang mencapai ketuntasan belajar pada pra siklus $12, \%$, pada siklus I 15,63, dan pada siklus II menjadi $84,38 \%$. Dapat disimpulkan bahwa dengan penerapan model pembelajaran Discovery Learning melalui Google Classroom berbantukan Whatsapp Group berbasis daring pada masa pandemi Covid-19 dapat meningkatkan keaktifan dan hasil belajar kompetensi/ materi teks eksplanasi siswa kelas VIII A SMP Negeri 3 Bojong.
\end{abstract}

Article History

Received: 04-02-2021

Revised: 11-03-2021

Published: 04-04-2021

\section{Key Words:}

Discovery Learning,

Activeness,

Learning Outcomes,

Competency.

\section{Sejarah Artikel}

Diterima: 04-02-2021

Direvisi: 11-03-2021

Diterbitkan: 04-04-2021
Kata Kunci:
Discovery Learning, Keaktifan, Hasil Belajar, Kompetensi.

How to Cite: Nuryaningsih, W. (2021). Penerapan Model Discovery Learning Berkolaborasi Google Classroom dan WhatsApp Group untuk Meningkatkan Kompetensi Siswa dalam Menulis Teks Eksplanasi. Jurnal Paedagogy, 8(2). doi:https://doi.org/10.33394/jp.v8i2.3540 


\section{Pendahuluan}

Dalam pembelajaran Bahasa Indonesia ada empat keterampilan yang dicapai siswa yaitu keterampilan mendengarkan, keterampilan berbicara, keterampilan membaca, dan keterampilan menulis. Keterampilan mendengarkan dan dan membaca merupakan keterampilan reseptif, artinya siswa diharapkan mempunyai kemampuan menerima pesan. Berbicara dan menulis merupakan keterampilan yang produktif, artinya siswa diharapkan mempunyai kemampuan untuk mengungkapkan gagasan menggunakan bahasa lisan atau tulisan.

Pembelajaran Bahasa Indonesia SMP/MTs pada Kurikulum 2013 adalah pembelajaran berbasis teks. Kompetensi yang harus dicapai siswa dalam teks tersebut ialah memahami dan memroduksi teks, baik lisan maupun tulisan dalam berbagai konteks. Jenis teks yang harus dikuasai siswa kelas VIII SMP/MTs antara lain teks berita, teks iklan, teks eksposisi, teks ulasan, dan teks eksplanasi. Salah satu keterampilan menulis yang harus dikuasai siswa adalah menulis teks ekplanasi.

Banyak penelitian yang telah dilakukan mengenai keterampilan menulis teks ekplanasi seperti penelitian Utin Faradila (2015) dan (Rohman, Rasna, and Darmayanti 2019), dari hasil penenlitian tersebut menujukkan bahwa pembelajaran menulis teks ekplanasi penting dikuasai siswa untuk menghasilkan dan menambah pengetahuan. Melalui pembelajaran menulis siswa akan memiliki pengetahuan dan keterampilan mengungkapkan atau mengekspresikan gagasan(ide), pendapat, pemikiran, dan perasaan sehingga daya pikir dan kreativitas berkembang (Erizal, 2020).

Menurut Waluyo (2017) bahwa teks ekplanasi adalah jenis teks yang bertujuan menjelaskan bagaimana sebuah peristiwa atau kejadian berlangsung. Pada umumnya, peristiwa yang dijelaskan adalah peristiwa alami. Kosasih (2017) menyatakan bahwa teks ekplanasi adalah teks yang menjelaskan mengenai proses fenomena alam dan sosial. Teks ekplanasi bertujuan untuk menjelaskan proses pembentukan atau kegiatan yang terkait dengan fenomena-fenomena alam, sosial, ilmu pengetahuan dan budaya.

Menulis teks eksplanasi bukanlah sebuah keterampilan yang dapat dikuasai siswa hanya dengan memberi teori tentang teks ekplanasi mencakup pengertian, ciri-ciri, struktur teks, dan kebahasaan teks ekplanasi saja. Akan tetapi, menulis teks ekplanasi membutuhkan latihan yang berkali-kali karena keterampilan menulis tidak akan datang secara otomatis tanpa melalui proses latihan. Dalam kenyataannya para siswa, baru memahami konsep teks ekplanasi. Para siswa belum terampil menulis teks eksplanasi sebagaimana yang diharapkan Kurikulum 2013 sesuai Kompetensi Inti (KI) ke-4 yaitu mencoba, mengolah, dan menyaji dalam ranah konkret (menggunakan, mengurai, merangkai, memodifikasi, dan membuat) dan ranah abstrak (menulis, membaca,menghitung, menggambar, dan mengarang) sesuai dengan yang dipelajari di sekolah dan sumber lain yang sama dalam sudut pandang/teori. Kompetensi Dasar (KD) 4.10 Menyajikan informasi,data dalam bentuk teks eksplanasi proses terjadinya suatu fenomena secara lisan dan tulis dengan memperhatikan struktur, unsur kebahasaan, atau aspek lisan.

Dengan adanya Pandemi Covid-19 dan pembatasan pergaulan sosial termasuk dalam kegiatan pembelajaran secara tatap muka tidak bisa dilaksanakan sehingga pembelajaran dilaksanakan jarak jauh secara daring. Terjadi perubahan dimensi waktu belajar dari pembelajaran tatap muka menjadi pembelajaran kelas maya. Terlebih sejak diterbitkannya Surat Edaran Kemendikbud Nomor 15 tahun 2020 tentang Pedoman Penyelenggaraan Belajar di Rumah dalam masa darurat penyebaran Covid-19, pembelajaran dilakukan secara jarak jauh, baik daring maupun luring. Tantangannya guru merasa sulit untuk membuat rencana 
pembelajaran, terjadinya perubahan dari kelas yang terkontrol menjadi kelas maya yang sulit dikontrol, pembelajaran daring memerlukan kuota internet yang mahal dan tidak semua orang tua bisa membelikan handpone untuk anaknya.Tujuan Pemebelajaran Jarak Jauh melalui daring untuk mencegah penularan Covid-19, pemenuhan hak belajar siswa, dan melindungi semua warga sekolah dari dampak buruk Covid-19. Hal ini membutuhkan kerja sama yang harmonis antara sekolah, guru, orang tua dan siswa agar siswa terpenuhi haknya untuk mendapatkan layanan pendidikan selama darurat Covid-19.

Penggunaan media aplikasi Google Classroom dapat dimanfaatkan sebagai media pembelajaran jarak jauh untuk membantu meningkatkan keaktifan dan hasil belajar siswa. Desain dari Google Classroom sudah tidak asing lagi bagi siswa karena mereka sudah menggunakan beberapa produk dari Google Via akun Google Apps. Kelebihan aplikasi Google Classroom dibandingan dengan aplikasi lain yaitu aplikasi Google Classroom dapat digunakan untuk membuat dan mengelola kelas, tugas, nilai serta memberikan masukan secara langsung. Melalalui Google Classroom siswa dapat memantau materi dan tugas kelas, berbagi materi dan berinteraksi dalam kelas atau melalui email, mengirim tugas dan mendapatkan masukan nilai secara langsung. Pembelajaran dengan penggunaan Google Classroom ini memiliki kelebihan untuk mempermudah siswa dalam belajar (Darmawan, 2019).

Berdasarkan hasil wawancara dengan beberapa siswa melalui What App Group pada hari Kamis tanggal 8 Oktober 2020 dan hasil refleksi guru setelah pembelajaran keterampilan menulis diketahui bahwa pembelajaran keterampilam menulis teks ekplanasi masih mengalami masalah dikarenakan: Pertama,siswa mengalami kesulitan menuangkan idea tau gagasan ke dalam tulisan. Kedua, siswa kesulitan menuangkan jawaban apa, mengapa, kapan, dan bagaimana yang ada dalam pikirannya ke dalam bentuk tulisan. Ketiga, siswa kurang memerhatikan PUEBI dan ketidakefektifan kalimat dalam teks ekplanasi. Keempat, kurangnya berlatih menulis teks eksplanasi. Dan Kelima, pendekatan pembelajaran yang belum tepat dalam pembelajaran jarak jauh menulis teks ekplanasi yang digunakan guru terutama pada masa pandemi Covid-19. Hal tersebut terlihat pada nilai latihan menulis siswa yang belum mencapai Kriteria Ketuntasan Minimal (KKM) berada di bawah 75. Hasil Penilaian Tengah Semester mata pelajaran Bahasa Indonesia yang dilaksanakan hari Rabu tangal 7 Oktober 2020 adalah 13 (40,6\%) dari 32 siswa yang sudah mencapai KKM, sedangkan $19(59,3 \%)$ siswa belum mencapai KKM. Berdasarkan wawancara dan instropeksi diri guru, dalam pembelajaran jarak jauh guru masih menggunakan metode pembelajaran yang kurang menarik perhatian para siswa.

Berdasarkan permasalah tersebut, menunjukkan bahwa keterampilan menulis siswa masih rendah. Jika dibiarkan akan berpengaruh pada pembelajaran berikutnya. Pembelajaran perlu ditindaklanjuti agar lebih inovatif dan metode pembelajaran yang dipilih diharapkan dapat meningkatkan keterampilan menulis khususnya menulis teks eksplanasi. Salah satu upaya yang dilakukan guru adalah penerapan model pembelajaran yang dapat memotivasi dan meningkatkan keaktifan siswa dalam menulis teks ekplanaasi adalah model Discovery Learning berbasis daring berbantukan Google Classroom dan Whatsapp Group. Ada dua alasan dipilihnya model Discovery Learning dalam penelitian tindakan ini. Pertama, model ini menekankan keaktifan siswa dalam proses pembelajaran. Kedua, model Discovery Learning mempunyai keunggulan antara lain a) melatih siswa belajar mandiri, sangat sesuai dengan kondisi Pandemi Covid-19 saat ini, b) dapat membangkitkan motivasi siswa untuk belajar, c)siswa bisa memperoleh pengetahuan mandiri sehingga lebih melekat di memorinya, d) mudah dilaksanakan dalam pembelajaran, sintaknya jelas. 
Ada enam tahapan dalam pelaksaaan pembelajaran model discovery learning. Pertama, stimulation (stimulasi/pemberian rangsangan). Pada tahap ini, guru memberi rangsangan kepada siswa, rangsangan yang diberikan dapat berupa pertanyaan. Kedua, problem statement (pernyataan/identifikasi masalah). Pada tahap ini, siswa diberi kesempatan untuk mengidentifikasi masalah dari rangsangan yang diberikan untuk dijadikan hipotesis. Ketiga, data collection (pengumpulan data). Pada tahap ini, guru memberi kesempatan kepada siswa untuk mengumpulkan informasi sebanyak-banyaknya yang relevan untuk membuktikan benar atau tidaknya hipotesis. Keempat, data processing (pengolahan data). Pengolahan data merupakan kegiatan megolah data dan informasi yang telah diperoleh siswa. Kelima, verification (pembuktian). Pada tahap ini siswa melakukan pemeriksaan secara cermat untuk membuktikan benar atau tidaknya hipotesis yang ditetapkan dengan temuan alternatif dihubungkan dengan hasil data procesing. Keenam, generalization (menarik kesimpulan atau generalisasi). Tahap generalisasi/menarik kesimpulan merupakan proses menarik kesimpulan yang dijadikan sebagai prinsip umum dan berlaku untuk semua kejadian atau masalah yang sama, dengan memperhatikan hasil verifikasi (Erizal, 2020).

Menurut Eko (2017) bahwa model Discovery Learning mempunyai kekurangan, yaitu(1) siswa harus memiliki kesiapan dan kematangan mental dalam mengikuti pembelajaran,dan (2) siswa harus berani dan berkeinginan untuk megetahui keadaan sekitarnya dengan baik. Penelitian sebelumnya yang dilakukan dalam menerapkan model Discovery Learning sebagai pilihan yang dapat dinyatakan berhasil untuk meningkatkan hasil belajar dan motivasi siswa dalam pembelajaran (Mahartati, 2017; Azkiya and Isnandab, 2018; Susmiati, 2020; Setiarini, 2016; Fitriana, 2019; Nurmiati, 2020)

Adapun penelitian ini bertujuan untuk mendiskripsikan peningkatan keaktifan dan hasil belajar menulis teks eksplanasi pada mata pelajaran Bahasa Indonesia dengan penerapan model pembelajaran Discovery Learning melalui Google Classroom berbantukan Whatsapp Group berbasis daring pada masa pandemi Covid-19 di SMP Negeri 3 Bojong.

\section{Metode Penelitian}

Penelitian ini menggunakan penelitian tindakan kelas, yakni dengan pendekatan kualitatif dan kuantitatif. Data kualitatif diperoleh dari lembar observasi dari setiap tindakan atau proses pembelajaran dan data kuantitatif diperoleh dari tes akhir setiap siklus (hasil pembelajaran). Pelaksanaan penelitian direncanakan dalam bentuk siklus. Masing-masing siklusnya dilaksanakan dengan empat tahap, yakni tahap perencanaan, tahap pelaksanaan, tahap observasi, dan tahap refleksi. Penelitian ini dilaksanakan di SMP Negeri 3 Bojong Kabupaten Pekalongan tahun pelajaran 2020/2021. Subjek penelitian ini adalah siswa kelas VIII A berjumlah 32 siswa (17 siswa perempuan dan 15 siswa laki-laki), yang berlansung selama delapan pekan. Ada dua macam data dalam penelitian ini, yaitu (1) siswa sebagai sumber data primer berkaitan dengan hasil belajar yang diperoleh ketika penilaian. Data primer berupa hasil pre test pada kondisi awal, siklus I, dan siklus II, data pengamatan keaktifan siswa, dan data angket siswa;(2) teman sejawat (sebagai observer, melalui Whatsapp Group), sebagai sumber data sekunder yaitu berdasarkan pengamatan selama pembelajaran daring yang dilakukan oleh teman sejawat dan data pendukung lainnya.

Data kualitatif dan kuantitatif diperoleh secara tes dan nontes. Teknik tes meliputi tes tertulis yang menghasilkan data kuantitatif. Teknik nontes melalui kegiatan observasi, dokumentasi (tangkap gambar percakapan siswa pada saat wawancara melalui Whatsapp Call) dan angket kepuasaan siswa selama pembelajaran teks ekplanasi yang disampaikan melalui link berisi pertanyaan dalam Whatsapp Group. Data kuantitatif yaitu yang diperoleh 
dari hasil tes divalidasi dengan validasi isi. Untuk data kualitatif divalidasi melalui triangulasi sumber yaitu hasil pengamatan kolaborator terhadap guru (peneliti), hasil pengamatan siswa dan angket. Nilai hasil tiap-tiap tes dihitung jumlahnya dalam satu kelas, kemudian dihitung dalam persentase.

Kriteria penilaian dalam penentuan keberhasilan siswa disesuaikan dengan standard nilai yang ditentukan sekolah. Indikator keberhasilan siswa pada pembelajaran teks eksplanasi yakni minimal $75 \%$ keaktifan siswa dan guru selama proses pembelajaran. Sedangkan keberhasilan hasil belajar teks eksplanasi ditentukan sesuai dengan ketentuan minimal 75\% siswa mendapatkan nilai sesuai Kriteria Ketuntasan Minimal (KKM) yang sudah ditetapkan oleh SMP Negeri 3 Bojong, yaitu minimal nilai 75.

\section{Hasil Penelitian dan Pembahasan}

Deskripsi keaktifan belajar pada kondisi awal sebelum adanya tindakan dengan Discovery Learning, melalui pengamatan dengan WhatsApp Group yang kurang aktif 21 siswa $(65,62 \%)$, cukup aktif 9 siswa $(28,13 \%)$,dan yang aktif 2 siswa (6,25\%). Ini berarti siswa kurang memperhatikan tujuan dan ketertarikan pembelajaran yang hanya satu arah dari guru dan siswa kurang diaktifkan. Sebelum dilakukan tindakan siklus dalam penelitian, dilaksanakalah pra sikuls penelitian. Kegiatan ini merupakan kegiatan tes awal (pre test) materi pembelajaran teks eksplanasi. Kegiatan ini untuk menjajaki tingkat pengetahuan, pemahaman, keerampilan siswa sebelum medapatkan perlakuan atau tindakan. Pre test berupa soal pilihan ganda berjumlah 20 soal yang disampaikan melalui link google form pada gawai siswa, diikuti oleh 32 siawa kelas VIII A dengan capaian: rata-rata kelas 69, nilai tertinggi 72, nilai terendah 26, dengan standar deviasi 9, dengan ketuntasan 12,5\% (lima siswa yang tuntas). Berdasarkan tes awal/pretest ini menunjukkan bahwa kompetensi siswa dalam pengetahuan, pemahaman, dan keterampilan teks eksplanasi masih rendah. Siswa yang sudah tuntas mencapai KKM (75) hanya 4 siswa (12,5\%), dengan rata-rata kelas di bawah KKM.

Pada siklus I, peneliti mengadakan pembelajaran dengan alokasi waktu 4x40 menit dua kali pertemuan. Melalui Whatsapp Group VIII A yang dibuat sebelumnya, guru meminta siswa bersama-sama berdoa untuk memulai pembelajaran teks ekplanasi menggunakan model Discovery Learning. Guru menyampaikan indikator pencapaian kompetensi, tujuan pembelajaran, menjelaskan penilaian yang akan dilakukan dengan cara observasi dan tes tertulis melalui Google Classroom. Selanjutnya guru melakukan apersepsi dan motivasi tengan manfaat dalam kehidupan belajar teks ekplanasi. Pada kegiatan inti guru menerapkan pembelajaran teks ekplanasi melalui model pembelajran Discovery Learning, tahap pertama Stimulus (Pemberian Rangsang) siswa diberi materi melalui Google Classroom berbantukan Whatsapp Group tentang karakteristik dan struktur teks ekplanasi. Guru memberi contohcontoh teks eklapnasi kemudian setelah mempelajari, siswa mengajukan pertanyaan yang relevan dengan materi. Tahap kedua, Problem Statement (Identifikasi masalah) guru memberikan permasalahan yang berkaitan dengan struktur teks eksplanasi. Tahap ketiga, Data Collection (Pengumpulan Data) siswa mempelajari ciri-ciri teks ekplanasi dari buku Bahasa Indonesia yang sudah dipinjamkan sebelum BDR (belajar di rumah). Tahap keempat, Data Processing (Pengolahan Data) Siswa mengerjakan latihan dua soal tentang menentukan gagasan utama paragraf teks eksplanasi. Tahap kelima, Verifikasi (Pembuktian) Siswa mempresentasikan hasil kerjanya melalui google classroom dan guru mengoreksinya. Tahap keenam, Generalisasi (menyimpulkan) Siswa dibimbing guru menyimpulkan karakteristik, ciri-ciri, dan struktur teks ekplanasi. Selanjutnya pada kegiatan penutup guru dan siswa 
merefleksi terkait pembelajaran, memberi tugas tentang menentukan gagasan utama paragraf teks eksplanasi, dan menginformasikan kegiatan berikutnya yaitu post tes.

Tabel 1. Rekap hasil Belajar Siklus I

\begin{tabular}{|c|c|c|c|}
\hline No & Kriteria & Nilai & Keterangan \\
\hline 1 & Tertinggi & 84 & \\
\hline 2 & Terendah & 62 & \\
\hline 3 & Rata-rata & 73 & \\
\hline 4 & KKM & 75 & \\
\hline 5 & Jumlah siswa yang mencapai KKM & 20 & $62,54 \%$ \\
\hline 6 & Jumlah siswa yang belum tuntas & 12 & $37,5 \%$ \\
\hline 7 & Standar deviasi & 6 & \\
\hline
\end{tabular}

Selama kegiatan pembelajaran berlangsung, guru mitra(guru kolaborasi yang juga masuk ke Google Classroom dan Whatsapp Group) mengamati proses kegiatan pembelajaran mengunakan lembar observasi pembelajaran yang sudah dibuat oleh guru peneliti pada tahap persiapan. Guru juga mengamati keaktifan siswa selama proses pembelajaran. Indikator/aspek yang diamati yaitu, kecepatan merespon pembelajaran menggunakan Whatsapp Group dan Google Clasroom, aktif berpendapat, bertanya langsung ke guru jika mengalami kesulitan melalui Whatsapp , presentasi tugas yang diberikan guru, dan ketepatan mengumpulkan tugas.

Tabel 2. Keaktifan Belajar Siswa Pasa Siklus I

\begin{tabular}{clc}
\hline No. & Kriteria & Siklus I \\
\hline 1 & Kurang aktif & 7 siswa $(21,87 \%)$ \\
2 & Cukup Aktif & 16 siswa $(50 \%)$ \\
3 & Aktif & 9 siswa $(28,13 \%)$ \\
\hline
\end{tabular}

Berdasarkan hasil angket menunjukkan bahwa siswa sangat tertarik mengikuti pembelajaran dengan model Discovery Learning melalui daring 48,39\%, sangat senang belajar dengan aplikasi Whatsapp Group dan Google Classroom 58,06\%, mendapat tambahan motivasi belajar 74,19\%, lebih memahami materi 54,84\%. Peneliti berkolaborasi dengan guru seprofesi untuk melakukan pengamatan kemampuan guru dan aktivitas siswa selama pembelajaran dengan model Discovery Learning melalui Whatsapp Group dan Google Clasroom. Dari pengamatan kolaborator terhadap guru penenliti temuannya:(1) dalam menyampaikan materi (tahap stimulasi) karaketristik teks ekplanasi belum banyak melibatkan siswa, (2) dalam penyampaian tujuan pembelajaran terlalu singkat,(3) guru kurang mendorong siswa untuk bertanya jawab, dan (4) alokasi waktu yang dimanfaatkan kurang efektif untuk menggali potensi siswa melalui pesan suara dengan Whatsapp Group.

Dari pengamatan terhadap kemampuan dan keaktifan siswa diperoleh temuan berikut:(1) tiga siswa terlambat mengikuti pembelajaran dengan membuka Whatsapp Group dengan alasan signalnya sulit dan kuota internetnya habis, (2) beberapa siswa belum paham tentang materi yang disajikan guru melalui Google Clasroom, (3) dua siswa yang kesulitan bergabung ke Google Classromm. Melalui kegiatan wawancara diperoleh keterangan bahwa siswa senang dengan kegiatan pembelajaran dengan Discovery Learning untuk berlatih kemandirian,hanya mereka tetap menginginkan tetap bisa belajar secara berkelompok. Melalui jurnal pembelajaran yang disusun guru peneliti diperoleh keterangan bahwa siswa belum maksimal mengikuti pembelajaran secara daring. Masih ada yang harus dibangunkan dari tidur oleh orang tuannya untuk mengikuti pembelajaran karena belajar di rumah dirasa seperti libur. 
Sebagai refleksi, berdasarkan pengamatan pada saat tindakan dilakukan, keaktifan siswa menunjukkan peningkatan pada kondisi awal masih pasif, pada siklus I ada peningkatan dan perkembangan perilaku siswa yaitu siswa yang aktif dari kondisi awal hanya 2 orang yang aktif $(6,25 \%)$, menjadi 9 orang siswa yang aktif $(28,13 \%)$ jadi ada peningkatan $21,88 \%$. Dari rekap hasil belajar siswa dengan jumlah siswa yang telah memenuhi KKM dari kondisi awal hanya 12,5\% meningkat menjadi $62,54 \%$ berarti ada peningkatan 53,04\%. Indikator keberhasilan dari penelitian ini adalah $75 \%$, berarti belum tercapai. Hal ini perlu perbaikan pada tahap tindakan dengn model Discovery Leaning pada siklus II.

Setelah seluruh perencanaan disiapkan, proses pembelajaran dilaksanakan di kelas VIII A sesuai jadwal yaitu Selasa, 3 November 2020 dan Rabu, 3 November 2020, masingmasing 2 X 40 menit. Dengan langkah-langkah yang sama dengan siklus I menggunakan model Discovery Learning, yang membedakan adalah materi pembelajarannya yaitu kaidah kebahasahaan teks ekplanasi dan menulis teks ekplanasi, dengan stimulus siswa diberi gambar-gambar peristiwa alam(banjir, tanah longsor, dan gempa bumi) serta gambar peristiwa sosial.

Keaktifan siswa dalam pembelajaran siklus II berdasarkan pengamatan kolabolator dan guru peneliti sebagai berikut: 25 orang siswa aktif $(78,12 \%), 2$ orang siswa cukup aktif $(6,25 \%)$, dan 5 orang siswa kurang aktif (15,63\%). Discovery Learning Berdasarkan hasil angket menunjukkan bahwa siswa sangat tertarik mengikuti pemebelajaran dengan model Discovery Learning melalui daring 67,38\%, sangat senang belajar dengan aplikasi Whatsapp Group dan Google Classroom 72,25\%, mendapat tambahan motivasi belajar 79,87\%, lebih memahami materi 66,05\%.

Hasil pengamatan kolaborator melalui Whatsapp Group dan Google Classrom bahwa guru sudah banyak melibatkan para siawa dalam pemilihan stimulus materi teks ekplanasi, informasi tujuan dan cakupan penilaian sudah jelas dipahami para siswa, guru mendorong siswa untuk bertanya hal-hal yang belum diketahui melalui japri atau Whatsapp Group , dan alokasi waktu yang digunakan lebih efektif sampai siswa berlatih menulis teks ekplanasi. Melalui wawancara memakai pesan suara Whatsapp kepada beberapa siswa setelah pembelajaran diperoleh keterangan bahwa siswa sudah maksimal dalam berlatih menulis teks eksplanasi. Mereka aktif bertanya juga kepada temanya yang sudah paham dan membaca buku siswa (Buku Bahasa Indonesia SMP/MTs Kelas VIII penerbit Kemendikbud) yang sudah dibagikan sebelum belajar di rumah.

Tabel 3. Rekap Hasil Belajar Siklus II

\begin{tabular}{llll}
\hline No & Kriteria & Nilai & Keterangan \\
\hline 1 & Tertingi & 88 & \\
2 & Terendah & 68 & \\
3 & Rata-rata & 79 & \\
4 & KKM & 75 & \\
5 & Jumlah yang siswa mencapai KKM & 27 & $84,38 \%$ \\
6 & Jumlah siswa yang belum tuntas & 5 & $15,62 \%$ \\
7 & Satandar deviasi & 6 & \\
\hline
\end{tabular}

Nilai rata-rata kelas mengalami kenaikan 6 dari 73 pada siklus I menjadi 79 pada siklus II. Berdasarkan rekap hasil belajar siawa dengan jumlah siswa yang memenuhi KKM dari siklus I sebanyak 20 orang $(62,54 \%)$ meningkat pada siklus II menjadi 27 siswa $(84,32 \%)$ berarti ada peningkatan $21,78 \%$, sedangkan indikator keberhasilan dalam penelitian ini $75 \%$ berarti sudah tercapai. Berdasarkan pengamatan kolaborator selama proses pembelajaran, aktivitas siswa menunjukkan peningkatan atau perkembangan perilaku siswa yaitu siswa yang aktif di 
siklus I sebanyak 9 orang siswa(28,13\%) di siklus II menjadi 27 orang siswa yang aktif $(78,12 \%)$ berarti ada peningkatan $49,99 \%$. Melihat indikator keberhasilan yang memenuhi KKM 75\%, pada siklus II ada 27 siswa yang memenuhi KKM bahkan melebihi KKM $(84,38 \%)$ berarti indikator keberhasilan sudah tercapai dan ini memenuhi harapan peneliti.

Perkembangan keaktifan belajar siswa pada proses pembelajaran teks ekplanasi menggunakan model pembelajaran Discovery Learning berbantukan Google Classroom dan Whatsapp Group dapat dilihat dari tabel berikut.

Tabel 4. Keaktifan Belajar Siswa

\begin{tabular}{lllll}
\hline No. & \multicolumn{1}{c}{ Kriteria } & \multicolumn{1}{c}{ Kondisi Awal } & \multicolumn{1}{c}{ Siklus I } & \multicolumn{1}{c}{ Siklus II } \\
\hline 1 & Kurang Aktif & $21(65,62 \%)$ & $7(21,87 \%)$ & $5(15,63 \%)$ \\
2 & Cukup Aktif & $9(28,13 \%)$ & $16(50 \%)$ & $2(6,25 \%)$ \\
3 & Aktif & $2(6,25 \%) 9$ & $9(28,13 \%)$ & $25(78,12 \%)$ \\
& Peningkatan & - & $7(21,87 \%)$ & $16(50 \%)$ \\
\hline
\end{tabular}

Hasil belajar siswa dapat dilihat dari tabel berikut.

Tabel 5. Hasil Belajar Siswa

\begin{tabular}{lllll}
\hline No. & Kriteria & Kondisi Awal & Siklus I & Siklus II \\
\hline 1 & Nilai Tertingi & 76 & 84 & 88 \\
2 & Nilai Terendah & 26 & 62 & 68 \\
3 & Nilai Rata-rata & 69 & 73 & 79 \\
& KKM(75) & $12,5 \%$ & $15,63 \%$ & $84,32 \%$ \\
& Peningkatan & - & $12,49 \%$ & $71,83 \%$
\end{tabular}

Rentang nilai perolehan dapat dilihat pada table berikut.

\begin{tabular}{llll}
\hline Rentang Nilai & Pra Siklus & Siklus I & Siklus II \\
\hline $0-55$ & 1 & 0 & 0 \\
$56-65$ & 15 & 3 & 0 \\
$66-75$ & 16 & 9 & 8 \\
$76-85$ & 4 & 20 & 21 \\
$86-100$ & 0 & 0 & 3 \\
\hline
\end{tabular}

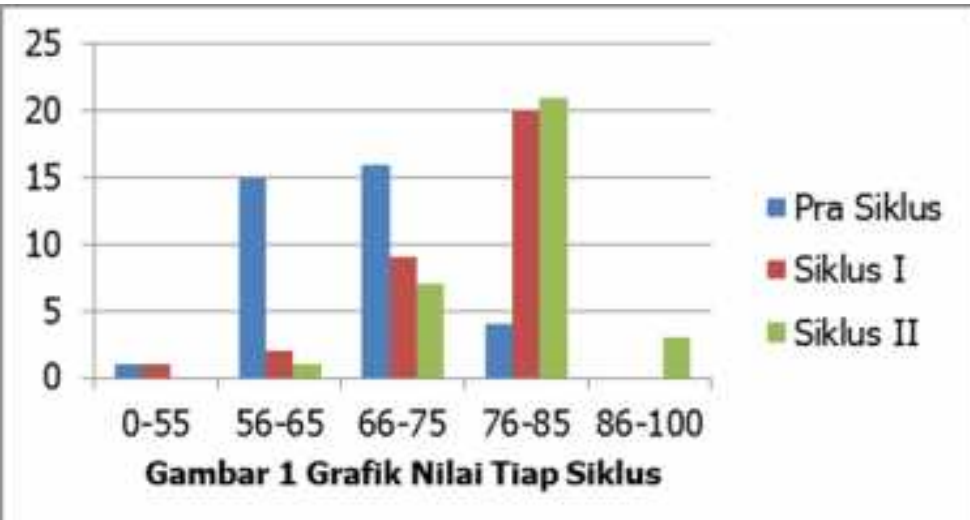

Hasil tes siklus II menunjukkan adanya peningkatan rentang nilai 86-100 jika dilihat dari rata-rata kelas siklus II adalah 79 , maka nilai siswa secara klasikal telah mencapai ketuntasan belajar. Bila dikonfirmasikan dengan kriteria tingkat keberhasilan termasuk B (baik). Jika dibandingkan dengan hasil siklus I dengan siklus II terjadi peningkatan yang baik yaitu sebesar 3. Masih ada tiga siswa (9,38\%) yang belum mencapai KKM 75 dan belum 
biasa mengikuti pembelajran Bahasa Indonesia materi teks eksplanasi, baik mulai dari kesiapan sampai pelaksanaan siklkus II. Guru sudah memberi bimbingan kepada siswa tersebut sampai melakukan home visit dan konsultasi dengan orang tua. Jika hal ini dikonfirmasikan dengan faktor kesiapan belajar dalam teori belajar yang ditulis (Oemar Hamalik: 205) bahwa siswa yang telah siap belajar hasil belajarnya akan baik. Sebaliknya jika faktor kesiapannya rendah hasil belajarnya cenderung rendah. Hasil belajar menunjukkan bahwa pembelajaran teks ekplanasi menggunakan model pembelajaran Discovery Learning berbantukan Google Classroom dan Whatsapp Group dapat meningkatkan keaktifan dan hasil belajar siswa kelas VIII A SMP Negeri 3 Bojong Kabupaten Pekalongan semester gasal tahun pelajaran 2020/2021.

\section{Kesimpulan}

Kesimpulan yang diperoleh dari hasil penelitian ini bahwa pelaksanaan model pembelajaran Discovery Learning berkolaborasi dengan Google Classroom dan Whatsapp Group pada masa Pandemi Covid-19 dapat meningkatkan keaktifan belajar siswa kelas VIII A SMP Negeri 3 Bojong Kabupaten Pekalongan semester gasal tahun pelajaran 2020/2021 dalam pembelajaran kompetensi/materi teks eksplanasi. Dari kondisi awal yang aktif hanya $6,25 \%$ meningkat menjadi $28,13 \%$ pada siklus I dan meningkat lagi menjadi $78,12 \%$ pada siklus II. Disamping itu model pembelajaran Discovery Learning berkolaborasi dengan Google Classroom dan Whatsapp Group pada masa Pandemi Covid-19 dapat meningkatkan hasil belajar siswa kelas VIII A dalam pembelajaran kompetensi/materi teks eksplanasi. Keberhasilan pembelajaran didasarkan dari semakin meningkatnya nilai rata-rata kelas yang dicapai kelas VIII A, yaitu dari 69 pada kondisi awal meningkat menjadi 73 pada tes siklus I dan meningkat lagi menjadi 79 pada siklus II.

\section{Saran}

Adapun saran yang dapat disampaikan berdasarkan hasil penelitian ini adalah; Pertama, dalam pembelajaran menulis khususnya menulis teks eksplanasi pada masa Pandemi Covid-19 ini, guru hendaknya menggunakan model pembelajaran Discovery Learning berkolaborasi dengan Google Classroom dan Whatsapp Group. Kedua, diharapkan siswa lebih aktif menggunakan fasilitas internet dan buku-buku untuk menambah wawasan keterampilan menulis teks eksplanasi pada khususnya dan kompetensi teks teks yang lain. Ketiga, hasil penelitian ini sebagai sumbangan pemikiran dan masukan bagi para guru dan pimpinan sekolah dalam upaya memahami pentingnya model pembelajaran Discovery Learning sebagai salah satu cara dalam meningkatkan keaktifan dan hasil belajar kompetensi dasar menulis pada masa Pandemi Covid-19.

\section{Daftar Pustaka}

Azkiya, Hidayati, and Romi Isnandab. (2018). "Pengaruh Model pembelajaran Discovery Learning Terhadap keterampilan Menulis Teks Eksplanasi Siswa Kelas VII Mts N Durian Tarung Padang ." Bahastra 38(2): 95-98.

Darmawan, Yuda. (2019). "Penggunaan Aplikasi Google Classroom Dalam Upaya Meningkatkan Hasil Belajar Matematika Pada Siswa Kelas X Sma Jurusan IPS." Pendidikan Matematika 1(1): 1-15.

Erizal, Asnita. Gani. (2020). "Pengaruh Penggunaan Model Discovery Learning Terhadap Keterampilan Menulis Teks Eksplanasi Siswa Kelas VIII SMP Negeri 20 Padang.” 
Jurnal Pendidikan Bahasa dan Sastra Indonesia 9(1): 23-31. http://103.216.87.80/index.php/pbs/article/view/108260.

Fitriana, F. (2019). Penerapan Model Discovery Learning pada Pembelajaran IPA Materi Tekanan untuk Meningkatkan Hasil Belajar Siswa. Jurnal Kependidikan: Jurnal Hasil Penelitian dan Kajian Kepustakaan di Bidang Pendidikan, Pengajaran dan Pembelajaran, 5(2), 100-108. doi:https://doi.org/10.33394/jk.v5i2.1805

Mahartati, I. (2017). Meningkatkan Motivasi dan Hasil Belajar Tematik Peserta Didik dengan Mengoptimalkan Penerapan Model Discovery Learning di SD Negeri 3 Cakranegara. Jurnal Kependidikan: Jurnal Hasil Penelitian dan Kajian Kepustakaan di Bidang Pendidikan, Pengajaran dan Pembelajaran, 3(2). doi:https://doi.org/10.33394/jk.v3i2.568

Nurmiati, B. (2020). Meningkatkan Motivasi dan Hasil Belajar Peserta Didik dengan Mengoptimalkan Penerapan Model Discovery Learning di SD Negeri 2 Cakranegara. Jurnal Paedagogy, 6(1), 1-7. doi:https://doi.org/10.33394/jp.v6i1.2523

Raihun, R. (2019). Penerapan Model Pembelajaran Discovery Learning untuk Meningkatkan Prestasi Belajar PPKn Peserta Didik Kelas IX.3 SMP Negeri 4 Praya Timur. Jurnal Kependidikan: Jurnal Hasil Penelitian dan Kajian Kepustakaan di Bidang Pendidikan, Pengajaran dan Pembelajaran, 5(2), 124-132. doi:https://doi.org/10.33394/jk.v5i2.1809

Rohman, Abdul, I Wayan Rasna, and Ida Ayu Made Darmayanti. (2019). "Penerapan Media Video Breaking News Di Televisi Guna Meningkatkan Keterampilan Menulis Teks Eksplanasi Pada Siswa Kelas Viii Smp Mutiara Singaraja." Jurnal Pendidikan Bahasa dan Sastra Indonesia Undiksha 9(2): 2614-4743(Cetak).

Setiarini, A. (2016). Meningkatkan Motivasi dan Hasil Belajar Peserta Didik dengan Mengoptimalkan Penerapan Pendekatan Saintifik Strategi Discovery Learning dan Metode Diskusi di SDN Model Mataram. Jurnal Kependidikan: Jurnal Hasil Penelitian dan Kajian Kepustakaan di Bidang Pendidikan, Pengajaran dan Pembelajaran, 2(1). doi:https://doi.org/10.33394/jk.v2i1.390

Sugiyono. (2015). Metode Penelitian dan Pengembangan Research and Development. Bandung: Alfabeta.

Susmiati, E. (2020). Meningkatkan Motivasi Belajar Bahasa Indonesia Melalui Penerapan Model Discovery Learning dan Media Video Dalam Kondisi Pandemi Covid-19 bagi Siswa SMPN 2 Gangga. Jurnal Paedagogy, 7(3), 210-215. doi:https://doi.org/10.33394/jp.v7i3.2732 